\title{
Curriculum and coronavirus: New approaches to curriculum in the age of uncertainty
}

\author{
Ivor F. Goodson ${ }^{1,2} \cdot$ John F. Schostak ${ }^{3}$
}

Accepted: 5 November 2020 / Published online: 5 January 2021

(C) UNESCO IBE 2021

\begin{abstract}
The coronavirus crisis has appeared like some vast, cruel sociological experiment. It has confined people to their homes, radically disturbed their taken-for-granted knowledge and beliefs, and forced them to alter behaviors once casually, even unthinkingly, employed in their everyday personal, working, and social lives. What has been learned? How might this experience stimulate a reimagining of the curriculum? More fundamentally, how might it lead to the development of a knowledgeable, intelligent, effective public, able to engage freely and equally in decision-making at all levels of social, cultural, political, and economic life, as a condition for personal freedom? This article explores the implications of "lockdown" or "confinement" to homes, which has suspended freedom of movement, limited the freedom to associate with others, and established rituals of hygiene regarding surfaces. These experiences of physical confinement and limitation of ordinary freedoms raise the central question of how to return to "normal" and, indeed, what will count as normal. In exploring the issues posed by these questions, this article offers an approach to pedagogical and curriculum practice that seeks to embed democratic practice at all levels of organization and interaction between individuals.
\end{abstract}

Keywords Education $\cdot$ Curriculum $\cdot$ Pedagogy $\cdot$ Coronavirus $\cdot$ Capitalism

The coronavirus crisis has appeared like some vast, cruel sociological experiment. It has confined people to their homes, radically disturbed their taken for granted knowledge and

Ivor F. Goodson

ivorgoodson@gmail.com

John F. Schostak

john@schostak.biz

1 Talinn University, Narva maantee 25, 10120 Tallinn, Estonia

2 Guerrand-Hermès Foundation for Peace, 199, Preston Road, Brighton, East Sussex BN1 6SA, UK

3 Education and Social Research Institute, Manchester Metropolitan University, 53 Bonsall Street, Brooks Building, Manchester M15 6GX, UK 
beliefs, and forced them to alter behaviors once casually, even unthinkingly, employed in their everyday personal, working, and social lives. What has been learned? How might this experience stimulate a reimagining of the curriculum? More fundamentally, how might it lead to the the development of a knowledgeable, intelligent, effective public, able to engage freely and equally in decision-making at all levels of social, cultural, political, and economic life, as a condition for personal freedom?

Perhaps the most striking phenomenon of this crisis has been confinement, or lockdown. How remarkably fast and easily at least half the world's population, around 3 billion people, were confined to their homes, grinding economies to a halt. The reality of the global spread of the disease overruled initial fantasies that it was little more than a "flu" that would "go away" until UK Prime Minister Johnson and later President Trump and many of his entourage in the White House and beyond were struck with its reality. Indeed, increasingly critical voices-coming from Black Lives Matter, climate and labor activists, and women's Me Too protests and movements, among others, have consistently and insistently called into question fundamental cultural, political, and economic narratives promoting individualism, competition, and elite power that assume the earth and its people are predominantly a source of exploitable profit. We see such critical reflection on experience as a kind of curricular process - a process of analysis and critique that is generative of issues and knowledge, as well as of practices about how to engage with others about how the world "works" or is "supposed to work". It re-imagines the "good society" as a society that promotes freedom and equality for all, not just wealth and safety for the few.

In the following, we begin by exploring how confinement can be storied in relation to the fundamental narratives of a given society. To do this, we outline the context of its antecedent historical, political, economic, and cultural conditions. We move then into a re-storying and reimagining of the curriculum as a project for contemporary educators, who are in a real sense the potential builders of new worlds.

\section{Storying confinement and its antecedents}

Confinement can be storied positively as protection or negatively as taking away freedoms, whether temporarily or permanently. The premier duty of a state is typically storied as ensuring the security and protection of its citizens from perceived and actual dangers. But what if the state itself is the source of danger? As defined by Weber (2014), states are designed to be the sole source of legitimate violence, sufficient to enforce rules and laws against their subjects through threats of punishment and confinement. In a Hobbesianlike conception of the world, the state becomes the Leviathan, a form of organization so terrifying it can subject and tame the natural instincts of warring individuals to produce discipline, order, and safety for those inside its borders against those outside - their potential enemies. For the political theorists Carl Schmidt and Leo Strauss - the theoreticians of choice for neoconservatives-politics is born in the distinction between friends and enemies. This distinction has been used to label even trade unionists fighting for fair wages and social justice as enemies of the state (Thatcher 1984) and other countries as comprising an "evil empire" and as threats to "our way of life" (Reagan 1983), so that we must build walls to prevent subversion by immigration (Miroff and Blanco 2020).

Such ideas have long been coded into the formal and hidden curricula of mainstream education. Indeed, the idea of confinement is in the very architecture of schools, which are designed to create boundaries between the disorder of the nineteenth-century laboring 
classes and the disciplinary, civilizing influence of schooling; or in the formation of classes based on age, gender, social status, and ability; or in the master-pupil power relationship. Contemporary mass schooling was born in the fear of the lower orders gaining democratic power over the ruling classes. As Lowe (1867a) put it, as increased voting rights were passed into law, "I believe it will be absolutely necessary that you should prevail on our future masters to learn their letters".

The lower classes as the "future masters" should "be educated that they may appreciate and defer to a higher cultivation when they meet it; and the higher classes ought to be educated in a very different manner, in order that they may exhibit to the lower classes that higher education to which, if it were shown to them, they would bow down and defer" (Lowe 1867b, p. 32). There are in effect two orders of voice-placed hierarchically and educated separately and differently - undermining the equality of voice and free and equal access to knowledge necessary to democracy. Hence, despite a democratizing move, a political frontier, as Mouffe (2018) calls it, is maintained between different class-based interests that continues a politics of "us" and "them". That, in turn, enables the emergence of "friend-enemy" politics that has so influenced today's neoconservatism (Schmitt 1985; Strauss 1988; Norton 2004). More generally, on a global scale as on a national scale, if under democracy—or indeed socialism—all voices are to contribute freely and equally so as to disband the us-them and friend-enemy axes as a basis for decision making in all areas of everyday life, why then is there any further need for boundaries and the states that enforce them? In that sense, as Bouton (2007) described, the wealth elites saw the emergence of democracy in the US as "the enemy" that had to be undermined and tamed.

In contemporary terms, neoconservatives, following Kristol (1995), the so-called father of American neoconservatism, consider democracy and liberal Enlightenment values to be the enemy. In The Closing of the American Mind, Allan Bloom (1987) saw in Plato's Republic the image of the non-democratic good society and advocated the "return" to a curriculum of "good books"-all prior to the Enlightenment and the corrupting influence of liberalization and democracy. In a real sense, then, the neoconservative political move was to engage in a cultural war against liberal Enlightenment trends in education and society. The strategy was driven by a lie, the Noble Lie, as Plato called it, a rationale needed to justify the emergence of classes of people: rulers, the military for defense, and, of course, workers to produce things. The modern version of the Noble Lie has dispensed with any notion of a philosopher-led society or of the guardians not owning property. It has been replaced by a myth of property-owning leadership elites. In this enchanted narrative, only by clearing away all the restrictions on economic behavior can self-made individuals arise who-as Kwarteng et al. (2012) put it in Britannia Unbound-unleash, like Prometheus, their powers of creativity to get their country back from foreign influence. Powered by unlimited greed, they become so rich that in effect they are "sovereign individuals" (Davidson and Rees-Mogg 1997), dependent upon no one and especially not upon a restrictive government. It is through the "invisible hand" of the free market that wealth inequalities are justified. It is a "life curriculum" in which only the naturally talented, the hardworking, and the risk-takers will win - they are the "natural" elites in a world that is "naturally" unequal.

However, like a dirty secret covered over by elites, it is clear that inequalities do not arise naturally (Dorling 2015). Hard work does not make a billionaire (Bloodworth 2016). Inequality is principally based upon inherited wealth and exploitation, underpinned by coercive laws of contract, property, patents, and copyright alongside threats by agencies of state enforcement, if not the use of outright violence, that restrict access to opportunities and resources. Various narratives are employed to naturalize inequality, whether of wealth, 
race, gender, faith, class, intelligence, talent, character, or age. This leads to a pervasive sense of unfairness, a lack of justice, and resentments that can always be exploited by the ruthless and reckless (Davis 2018) for a combination of political and criminal purposes. As a WHO report (2008) put it, such social injustice kills on a global scale.

The coronavirus pandemic reinforced inequality, with the rich self-isolating on their yachts and estates while the poor were crammed into overcrowded spaces. Indeed, as Spinney (2020) put it, "Historically, pandemics have been more likely to occur at times of social inequality, and discord". Audrey Lutz, executive director of the not-for-profit Multicultural Coalition, works with immigrants in an area of Nebraska hard hit by the disease. He stated: "The people in power are not affected by the decisions that they make. In our state, those people are white and privileged, while those who have to accept their decisions are minorities and immigrants — and they are paying a terrible price" (Pilkington 2020). As the disease progressed, this disparity became increasingly clear (Hirsch 2020; APM Research Lab 2020). The United Nations called it "a systemic human development crisis" that was compounding gender inequalities (Rivera et al. 2020). Specifically, confinement to the house led to a surge in domestic violence (McDonald 2020; Taub 2020). When lockdowns were eased and restrictions on movement relaxed as concerns about economic impacts on jobs and wealth creation rose, infections again rose. As Andrew Cuomo, the governor of New York, said, "The fundamental question, which we're not articulating, is how much is a human life worth? The faster we reopen, the higher the human cost because of more lives lost" (Pilkington 2020).

Can an alternative and better life curriculum be storied?

\section{Re-storying the life curriculum}

Reason-allied with powers of imagination, empathy toward others, and care for the natural world-tells a story quite different from reason applied coldly to risks within the contexts of exploitation of the natural world, precarity, and the fear of losing property, livelihoods and, indeed, one's health and life. It is the latter that Buchanan (Buchanan and Tullock 1962) drew upon in his public choice theory, which won him the Nobel Prize for economics and was influential in shaping the policies of both Thatcher and Reagan. A property-owning democracy would provide a policy lever to the extent that individuals make choices dependent upon whether those policies threaten, preserve, or enrich their property ownership. Under contemporary conditions of inequality, the propertyless will thus be increasingly marginalized; if they feel they are not being listened to, they will likely opt out of voting altogether and, as in current trends, be attracted to populist and extremist political organizations, parties, and leaders.

Such marginalization, however, is of little interest to those whose concern is wealth accumulation. Public choice theory-along with managerialist approaches focusing upon measurement, aligned with the management of revenues to increase dividends for shareholders - was part of a general movement toward the mathematization of economics through what came to be known as monetarism. This approach has been successfully embedded globally through the education of university students over the last half century. What resulted was an "econocracy" (Earl et al. 2017) for the governance of the world that could be modeled and imposed regardless of the real social, political, cultural, and economic impacts that people experienced in their homes, communities, and places of work. It 
resulted in the economic crash of 2008. Instead of this being a lesson, the dominance of the econocracy has continued zombie-like (Quiggin 2010).

The world economic crisis produced by the pandemic is already considered to be greater than the financial crisis of 2008, producing political and economic conditions more reminiscent of the 1930s. We have to change our thinking. How? Where might we look?

As many have commented, an alternative articulation of the Enlightenment and of modernity can be developed from a Spinozan-like rather than a Cartesian-like stream of thought and practice (Mack 2010). This puts us on track for a more radically democratic and cooperative approach to governance and economic organization than the competitive individualism of a "free" market economy dominated by corporate monopolies owned by billionaire families. Hence, Spinoza's political ideas have been picked up and reimagined, in particular by Negri (1991) and Balibar (1998), contributing to a radicalization of democratic theory and practice alongside the post-Marxist contributions of Laclau and Mouffe (1985). Spinoza has indeed been called the first democratic philosopher of the modern age (Ward 2014). His radical philosophical reading of Descartes did not split mind from body. Rather than seeing the mind as dominant over the body, the mind was instead seen as an idea of the body. That is, the mind is a product of the powers of the body. The educative tasks, as it were, of each individual are to draw out to their fullest he potential the powers of the body. Hence, if thought dominates feeling, then feeling is diminished and cannot contribute fully to the overall good of the body. The greatest benefit can be drawn, he argued, only if there is a co-equality, a democracy, as it were, of powers. Similarly, it was in each individual's interest to combine their powers with those of others to achieve a still greater benefit. If one individual or group of individuals dominates over others, the suppressed powers of the dominated cannot be fully developed. To gain the greatest benefit, the powers of all must be allowed to develop freely.

The freedom of the one depends on the freedom of all. Hence, in Balibar's (2010) formulation, freedom is co-extensive with equality. To emphasize this relationship, he called it égaliberté. Such ideas of the necessary interdependence of equality and freedom were common during the age that saw the critical democratic revolutions in America, France, and Haiti (Rosanvallon 2013). The question for many was how to create the society of equals (Rosanvallon 2013) implicit in the ideas underpinning revolutionary democratic discourses. In other words, a different life curriculum was possible.

Developments could be explored in utopian experiments like Robert Owen's New Lanark Mill, the further development of the cooperative movement by the Rochdale Pioneers, or indeed, the revolutionary zeal inspired by Marxism and anarchism. These kinds of discourses around freedom and equality focused attention upon the public and the relations between the individuals who composed it. If indeed there was to be equality of voice as a basis for freedom from oppression, then it stood to reason that all the means whereby one individual, group, class, or so-called "race" of people could dominate another should be abolished. Essential to this view was the idea of the co-equality of intelligence as the fundamental building block of an effective and educated public (Rosanvallon 2013).

This was exemplified in Jacotot's approach to teaching. As an exile from France due to his revolutionary ideas, he sought a means of discussing them with his students in Louvain, Belgium, where neither knew the language of the other (Rancière 1987). A book written in both languages was used as a means of communication. Through this shared space, each side overcame their ignorance of the language of the other. The conclusion drawn from this was that each individual is co-equally intelligent, and while each may be knowledgeable about something, or at least claim to have something to say, each is also ignorant of something, and their claimed knowledge can be tested or evaluated through discussion between 
co-equals. Thus, the ignorance of each is a motive for engaging in learning together by sharing knowledge critically and inventively through the use of their intelligence. But more than this, such knowledge co-equally produced, is to be employed in the public construction of the good society, the society of equals where all are free and equal.

If, then, one of the lessons of the crisis is that in the most marketized Anglo-Saxon states, most notably the US and the UK, there has been a real failure of communication between the hollowed-out government agencies and social collectivities, then as citizens, we need to "get our powers" of decision-making back. In each case, there has been widespread commentary about the chaotic nature of the government response. This is, in a sense, a logical result of a society that has largely handed over its powers of collective decision-making to the "free" market, a market dominated by corporate powers. It means that those societies that have gone furthest in this ideological handover have governments that are least able to communicate and guide their "publics" in times of crisis.

To get our decision-making powers back, we need to imagine otherwise.

\section{Imagining otherwise: Prefigurative curricula}

Like the political of Rancière (2001), the prefigurative moment is a paradoxical moment of égaliberté where new forms of relationship are glimpsed that are productive of alternative ways of seeing, knowing, experiencing, practicing, and conducting relationships for mutual benefit. Crucial to the imagining of new educational arrangements is that they must prefigure a world that can be sustained after the pandemic. Hence, we are looking for classrooms that prefigure in microcosm a world that is sustainable and democratic.

We need to relearn how to work together to share ideas and how to organize together to create resources that feed all our purposes, not just the purposes of a wealthy ownership class. We need to see how social organizations are the building blocks of a government that acts according to the expressed interests of all. For that, we need to relearn how to have a free and equal voice with others. Only then can we build narratives in which all people, regardless of race, ethnicity, gender orientation, faith, occupation, and age have an equal voice in decision-making; resources are allocated equally; and all organizations and institutions are democratically run.

To achieve this, we need to counter narrowly conceived notions of transmission that confine our voices to a given set of pre-planned guidelines created by remote elites. This implies that we also need to challenge the belief that government is rule over people rather than ways that collectives form agreements about how to rule and organize relations among themselves. It follows that we need to challenge neoliberal beliefs that, because we can rely on the automatic levers of the marketplace and rational choice theory to solve our problems, rationality and planning are no longer part of the government's brief. In a system of pandemic crisis, this clearly does not work. But this is symptomatic of a much wider, impending crisis. In fact, we live in risk societies where enormous uncertainties are part of our daily diet of existence. When such uncertainty is endemic, the governmental provision of platitudes and narratives of certainty becomes impossible. Its counter can be only prefiguring in peoples' practices, relationships, and forms of organization a different relationship between the "public" and their forms of governance. Indeed, rather than manufacturing the consent of a public to government policy, perhaps a more Dewey-like (Dewey 1927, 1980; Pinar 2019; Schostak and Goodson 2020) approach can be brought about, one in which education takes a central role in the formation of an actively democratic public. 
For this reason, it is imperative that educationalists begin to think of a curriculum that can work with and, in some sense, address the endemic uncertainty of this age. Hence, the notion that schooling can transmit certainties and verities through a pre-planned and preactive curriculum can no longer hold sway. We have to think of ways of moving beyond preactive planning by elites and top-down transmission into a more collective, cooperative, mutual pattern of learning. To take an example, governments are now entirely dependent on the development of knowledge by cooperating collectivities of scientists of how to solve this crisis. So - to follow the scientific model-under conditions of uncertainty, it is through intense local collaboration and transnational cooperation that a solution to this pandemic will come. It will not come from any place located within the free market. It will come from collective action among a group of practicing and scientific personnel working cooperatively and collegially to find a solution. This prefigures to some extent the model of how learning will need to take place in the age of uncertainty and pandemics.

\section{Toward an alternative pedagogy and curricular practice}

There has always been subversive potential for change, even in the most traditional classrooms. For example, Jackson's (1968) studies of Life in Classrooms, then widely regarded for their authentic flavor, argued:

As typically conducted, teaching is an opportunistic process. That is to say, neither the teacher nor his students can predict with any certainty exactly what will happen next. Plans are forever going awry and unexpected opportunities for the attainment of educational goals are constantly emerging...in the classroom as elsewhere, the best laid schemes suffer their usual fate. (Jackson 1968, p. 166)

This going awry can be seen either as failure of the transmission model, its subversion, or as creative moments in which "the seasoned teacher seizes upon these opportunities and uses them to his and his students' advantage". But this still implies an essentially hierarchical model of the knowledgeable teacher pouncing in order to bend the will and interests of the other in a teacher-led direction.

If the involvement of all students is to be our aim, then somehow a pedagogy firmly situated in the interactive reality of the classroom is required, a pedagogy that accepts and works with the individual interests and processes that are at the center of classroom learning. However, if "individual interests" are to be taken seriously, then it becomes more explicit that the hierarchy that imposes upon individual interests has to be suspended in some way. Steps toward this suspension of teacher power in favor of student interests has a long history, often emerging at times of national crisis: Think of Kilpatrick at the time of the Great Depression, Bruner at the time of the Sputnik crisis, and James and Stenhouse after the events of 1968. For them, each individual pupil exhibits the most positive response in the learning process when the information being dealt with somehow "meshes" with their interests:

A child's education (as opposed to schooling) can proceed only through the pursuit of his interests since it is only these which are of intrinsic value, [and further], whatever enables him to appreciate and understand his interest more fully and to pursue it more actively and effectively is education. (Wilson 1971, p. 67) 
Similarly, Dewey (1971, p. 22) saw:

the need of reinstating into experience the subject matter of the studies, or branches of learning. It must be restored to the experience from which it has been abstracted. It needs to be psychologized, turned over, translated into the immediate and individual experiencing within which it has its origin and significance...

Moreover:

If the subject matter of the lessons be such as to have an appropriate place within the expanding consciousness of the child, if it grows out of his own past doing, thinking and suffering and grows into application in further achievements and receptivities, then no device or trick or method has to be restored to in order to enlist "interest". The psychologized is of interest - that is, it is placed in the whole of conscious life so that it shares the work of that life. But the externally presented material, conceived and generated in standpoints and attitudes remote from the child, and developed in motives alien to him, has no such place of its own. Hence the recourse to adventitious leverage to push it in, to factitious drill to drive it in, to artificial bribe to lure it in. (Dewey 1971, p. 27)

Acknowledgment of the importance of the child's experience and interests and acceptance of these as valid knowledge content in classroom learning can lead to two distinctive alternative pedagogies and forms of curriculum development. The first, child-centered progressivism, would center on the child's interest and, in doing so, conclude that the pedagogy should allow children to direct their own learning. W. H. Kilpatrick's views are closest to advocating this pedagogy; for him, education starts where the child is so as to capitalize on the their personally directed activity springing from real interests, while "paradoxically... the teacher's aim is to give as little help as possible, that is, to give the least degree of direct help consistent with the best personal work on the part of the pupils" (Kilpatrick 1951, p. 307). A similar style of pedagogy is described by Charity James, in which "students formulate the questions they want to answer, identify the problems which they want to solve, create hypotheses for their solutions, test them and revise the hypotheses" (James 1968, pp. 65-66).

For James, as for Kilpatrick (1951, p. 65), the teacher is seen "as a consultant to students in their self-directed enterprise". This can be criticized by saying that there is an overdependence on "what pupils do themselves" (Kilpatrick 1951, p. 307). Such an emphasis seems ill suited to the interactive character of classroom learning, firstly because a major part of the rationale for classroom learning must surely turn on those aspects the pupil learns in interaction with peers and the teacher in order to aid the development of the pupil's interests and ideas into areas other than those the pupil might independently explore.

Secondly, it can be argued that part of a teacher's job is to ensure that pupil's work can go on uninterrupted since, as Jackson $(1968$, p. 111) put it, in the classroom "the crowds remain" to pull at the student's attention and divert the teacher's energy. However, if democratic principles and practices are part of the curriculum, can such problems of "control" be addressed differently? There is a danger that in our enthusiasm to extend and manage the interests of the other "we have become our own curriculum's ideal pupils; our resources are beautifully designed to satisfy not our pupils' intellectual demands, but our own!" (Armstrong 1974, p. 51).

Indeed, as Eraut et al. (1975), for example, were aware, the teachers who prepared learning packages generally learned a lot in the process of "sorting it all out". However, those 
who were to study them learned little because "in presenting the students with a completed analysis we were concentrating their attention on predetermined solutions at the expense of focusing it on either the nature of the problem or the analytic process itself"'

The challenge then is to move the pedagogic focus from the preactive situation, where it is divorced from the pupils, to the interactive situation, where the pupils are involved. By so changing the focus, learning becomes less a matter of mastering externally presented material and more a case of actively reconstructing knowledge. Thus, the process of "sorting it all out" becomes what Dewey called "the need of reinstating into experience the subject matter".

The curriculum project Man: A Course of Study, on which Bruner acted as consultant (Hanley et al. 1970), provides an example of doing this. Through open-ended discussion, where definitive answers may not be found and reflection upon one's own experience is valued, teachers legitimize a question-posing or inquiry method in which children use first-hand sources to draw hypotheses, draw conclusions, and are able to apply frameworks developed in one area to other areas. Similarly, Stenhouse's (1975) Humanities Curriculum Project provided a framework and evidence pack through which young people could debate sensitive and controversial issues. Importantly, it introduced the idea of the teacher as the "neutral chair". Even if the teacher ensures equality of voice, no matter how "neutral", the teacher remains the source of "legitimation", the one who sets the rules of debate and inquiry. Nevertheless, such examples seem to be first steps toward articulating Balibar's principle of égaliberté: In the curricular process, through the choices made and the conclusions drawn, if any are possible, each voice-teacher's and pupil's - is freely and equally able to express views, opinions, arguments. What is feared by teachers and maybe adults in general, perhaps, is losing control of the narrative. Shor (1996), for example, in enabling his students to establish their own "learning contracts", expressed this fear. Indeed, if children can do it all by themselves, what is the point of a teacher or a school curriculum?

The point perhaps, is that the teacher remains as a free and equal member of the circle of debate, able to provide their particular experience as a resource. Key to the debate is to form opinions about what counts as an informed choice or a sound conclusion. Raths (1971), for example, attempted to provide a working list of likely criteria for judging classroom activities: "All other things being equal, one activity is more worthwhile than another if it permits children to make informed choices in carrying out the activity and to reflect on the consequences of their choices". But clearly, lists of procedural principles and worthwhile activities might fall into the trap whereby preactive definition proscribes interactive interpretation. To avoid this, it is important for children to debate such criteria and develop their own frameworks of debate as an answer to the question "How do I/you know?". In a post-truth (Kakutani 2018) age of bullshit (Frankfurt 2005), passing as grounds for decision-making and action, it is not enough to call upon experts to do our thinking for us. When a president can propose - and be taken seriously_drinking disinfectant as a cure for Covid-19, future adults need to be able to reflect back upon their curricular experiences of critical debate in order not to be fooled into thinking it is a sensible course of action (Smith 2020). Indeed, the culture wars instituted by neoconservatives (Kristol 1995) have dangerously played out during the crisis, during which political demands to get back to work to save the economy after lockdown have been set against the advice of experts who are positioned as liberal "snowflakes" (Geoghegan and Fitzgerald 2020). This is nowhere better exemplified than in the demands by those who are driven by profit-making to return children to school and the downplaying of the real fears of parents and teachers whose experience of everyday life has been reorganized in terms of how to touch and treat surfaces and create safe spaces through social distancing. 
The critical role of education, curriculum matters for discussion, and what counts as truth for the public have long been the focus of critical pedagogies, from Freire (1972) to Giroux (1989, 2005; see also Sandlin et al. 2010). It is through such approaches that the "cultural wars" can be unpacked, revealing how authorized practices, discourses, and forms of organization serve the interests of particular elites and communities rather than others.

However, two additional points must be made if such approaches are to be drawn into schools. Firstly, and critically, while the focus in contemporary public discourses is typically on individual negotiation-quite often in classrooms and often on those organized in open ways-individual choices end up producing similar themes that can be pursued by groups of students. This is to be encouraged and nurtured. Indeed, those experienced in working with alternative pedagogies like this find that individual choices often emerge into collective projects and endeavors. So cooperative learning leads naturally to cooperative group behavior and engagement. This is one of the most important recommendations for an alternative pedagogy and alternative curriculum style.

The second point is crucial. The problem with traditional transitional models is that they fail to engage around two thirds of all pupils, a fatal and continual failing. Alternative pedagogies and curricula are searching for a different way to "engage" the student. We want students to get past the initial and fatal stumbling block. We are looking, in short, to cross "a pedagogic threshold", one that in effect takes us over the mental, cultural, economic, social, and political "confinement thresholds" revealed by the crisis. Once over these thresholds, all manner of educational possibilities emerge, along with some reinstatement of transmission pedagogy and engagement with existing disciplinary modes and bodies of knowledge. We are not presenting an either/or choice - rather a both/and choice. Once over the thresholds, which currently hold back two thirds of our students, so many educational avenues are opened up.

\section{Reimagining curriculum and pedagogy}

The day when primary aged children returned to school in France after weeks of confinement to their homes, a photo of them "playing" in the playground hit the front pages. Each child sat alone in a chalked square at some distance from the others. This image contrasted sharply with memories of a past "normal" and caused outrage. Where was the free association, the running, the touching? Inside the classroom, children sat far from each other, again in marked out "boxes" around their tables, their course of movement from one place to another organized by arrows pointing in the direction of travel so that one person could not bump into another.

How do we get back together again?

First, imagine this situation: a teacher spends two mornings and two afternoons with a group in a classroom each week (for a more detailed exegesis of this imagined classroom, see Goodson 2005b). The room is set up to reflect and resource the interests of all. There are photographs and paintings on the wall, media resources for learning, paints and brushes, as well as books and resource kits. And of course, there is an easy, mobile connection to the internet. The whole is deliberately designed to freely and equally facilitate curricula inquiry, debate, and the development of projects. What is the role of the teacher?

We see some students working alone, others asking the teacher to sit with them for supportive remarks ("Yes, that's good, go on"). Others demand specific and animated pointby-point argument, explanation, planning, and disagreement. With one group, the teacher 
appears serious, with another the relationship seems to be conducted through jokes, insults, and repartee. Rather than a strict center of control, there seems to be a creative and dynamic infrastructure underpinned by agreed principles of practice, according to which each individual is treated as an equal able to freely participate with others on projects of mutual benefit. Groups form and decompose according to need or whim. But, in general, individuals seem to act both independently and cooperatively according to mutual consent. The teacher's role seems as much defined by the students as by the teacher. There is here a powerful contrast between this free flow of relationship-building necessary for creating projects in common and the images of confinement, constraint, and isolation of the photos of children on their first day back from lockdown.

How can we imagine the steps from mental and physical lockdown to the freedom for co-equals to choose their associations with others as a basis to organize projects of mutual benefit and interest?

Confinement to home had already drawn upon internet-based peer-to-peer technologies such as Skype, Zoom, TikTok, and Fortnite both for keeping in touch with friends as well as for learning (Jones 2020). Indeed, it is commonplace for schools to employ digital communications infrastructures. Some see in this the possibility of emancipating learning and children from their classroom-bound confines (see, for example, the innovative work of Stephen Heppell (http://www.heppell.net). Indeed, this could a way of breaking into the curriculum (Schostak 1988; Fraser and Schostak 2005; Facer 2011) and creating emancipatory learning communities, but it could also be a powerful means of control through all-pervasive forms of "super surveillance" (Schostak 2014). Super surveillance, not just in schools but across communities, in the context of Covid-19 realities evokes the biopolitics of Foucault. Here, the contemporary aim is to digitize and monitor if not everything, then everything in life that matters to governing elites.

The formation of educational communities underpinned by communications infrastructures and technologies is not enough. The physicality of schools serves a traditional social function, as made clear in the political demands for a return to economic normality after lockdowns - in particular, the demand that children return to school, thus releasing parents to return to work and ensuring that the future workforce is "educated" and assessed in ways that are appropriate for employment. In school environments, children learn to live with the paradoxes of discourses of freedom under conditions of discipline and evaluation by adults; they learn as well to accept inequality of opportunity and access to resources (Schostak et al. 2020). Mainstream schooling has not led to any large-scale increase in social mobility or reduction in social inequality (Benn 2012; Berliner and Glass 2014; Blacker 2013; Reay 2017). Indeed, the crisis has exacerbated inequalities (Spinney 2020), in particular racial inequality (Oppel et al. 2020). The intention to bring about democratic forms of school organization, curriculum development, and teaching has to contend continually with such broader contextual realities.

It is an everyday struggle for both teachers and young people. Schools with their playgrounds, corridors, classrooms, and resources provide opportunities for conviviality, free association, and collective activity based on physical proximity, and they also enable the everyday encounters that lead to jealousies, annoyance with others, anger, and disagreement. To this, the crisis has added the fear of surfaces and the fear of touch. One child on his first day at school, having gone through social distancing proceduresstanding one meter apart from his friends as defined by a cross marked on the groundwhen told to move into the classroom looked back in fear at the student behind him and said in panic, "You're getting too close, you'll touch me". This new focus on the arrangement of the everyday of marked out surfaces underpinning social distancing 
and the fear of approaching and touching others brings into play fundamental curricular topics for debate and creative solution. This is not something that a teacher alone can resolve. These are real problems, not the artificial ones of many a problem-solving project asking children to use glue, paper, and cereal boxes; nor are they a collection of debating issues. They are drawn from my family, friends, and community now. How do I deal with them? Don't tell me, engage with me in my life. This is perhaps the lesson to be drawn from the letter to a teacher written by the School of Barbiana (1969), a small Italian school of young people who mutually educated each other without a teacher. Each had different knowledge, skills, and experiences that collectively created their curriculum of inquiry and practice.

In that sense, curriculum, learning, and teaching are a cooperative enterprise in which teacher and student look at a topic together, each presenting their own view and their own resources to the other, feeling their way through dialog toward a common perception and project.

For example, after "browsing" in the "environment", the student eventually says, "I want to do something on the Second World War". The teacher may be expected to provide a way forward but is also wanting to "let go" of their leadership role: "OK. Let's get started: Is anyone else interested? Who else can help? How do we organize our work? What resources are there, and where can they be found? There are some books and magazines in the library, there's an internet video we can look at, there are relevant internet-based communities of interest". Then follows a period during which the teacher can feel quite anxious about what's going on. There may be a lot of copying out of books, drawing pictures, cutting and pasting from the internet, unrelated bits and pieces of knowledge being collected, arguments, disagreements, social chit-chat; it may seem like useless knowledge and pointless debate, and so it may be. But a process of exploration is occurring, in which students find ways of working together, maybe unconsciously. Through debate, they feel around the topic and locate the real source(s) of its attraction-some problem or worry or preoccupation or powerful feeling related to it.

The teacher watches all this and tries to detect underlying themes and concerns in the group's busy activity. At the same time, the teacher tries to gently maintain it and keep from criticism of it. If there are disputes, the teacher may remind them of the process and the underlying principle of égaliberté to ensure the inclusion of each voice in debate, to sort out the underlying causes, and find ways forward. Through this, the students together with the teacher begin to get clearer about what is at issue: So, what we're really on about is the casual, pointless way people could get killed, in ways that couldn't make any sense to them. You live your whole life, have an education, a family, fillings in your teeth, and end up in a ditch after some minor skirmish with an unimportant enemy outpost that was going to withdraw one minute later anyway.

And isn't there something of that "pointlessness" underlying the fear of death through some pandemic, or climate disaster, or indeed, terrorism or nuclear war? These are not just "academic questions". But they may be thought of as safely distanced in time and somewhat abstracted from "now".

What if the immediate subject of exploration is much closer in time, much closer to home and community, and is happening now?

During the coronavirus crisis, at the very moment of lockdowns, people were also on the streets protesting: Black Lives Matter, Extinction Rebellion, as well as protests against the lockdowns and the wearing of masks. And at home, cases of domestic abuse rose alarmingly (McDonald 2020; Scotland 2020). Are these not suitable topics of school debate, to understand causes and explore solutions that might lead to different ways of life, social 
organization, and political order? In the view of the then UK and US governments, these were to be viewed as off-limits for schools (Busby 2020; Waxman 2020)?

These are big issues impacting people in the immediacy of their everyday lives. They demand knowledge as well as scientific, political, economic, social, and cultural forms of organization and infrastructure appropriate to their solution. In the debate, what makes the difference is the inclusion of each voice. This is the stage in education and curriculum development where the synthesis of different perspectives on ideas/theory/knowledge, forms of organization, and resources of all kinds are imperative in order to generate visions of the good society. Only in this way can students have a perspective on the whole issue, which then invites the questions: What further do we need to know and what can we do? These are questions about the prefigurative steps required if the issues are to be resolved and the vision of the good society is to be achieved.

Initial attempts to model prefigurative steps may be expressed in a piece of writing or some other form - artwork, video documentary, theater production-that integrates generalizations, facts, attitudes, forms of social, economic, political, and cultural organization and their entire view of the world. For teachers attracted to democratic philosophies, forms of organization and practice, particularly those in leadership roles, the paradoxical nature of their work becomes a curricular site of exploration and indeed, contest and struggle (Schostak et al. 2020). In her work with a consortium of mainstream schools, Hammersley-Fletcher (see Schostak et al. 2020) has helped school leaders construct a researchbased infrastructure enabling the embedding of democratic practices in the organization of teaching and learning. In particular, it is argued that to do this, the role of the teacher becomes that of the vanishing mediator (Jameson 1973). That is to say, teachers progressively reduce their role as students increase their capacity for independent research, curriculum development, and learning. In contexts that are often hostile to democratic inquiry and practice, this requires courage.

By aligning curriculum development, teaching, and learning with their everyday lives, the development of practices, knowledge, and local forms of organization are established at ground level in ways that are continually relevant for the formation and maintenance of an effective public.

The significance of this can be seen for example in Collier's (2020) reflections on capitalism after coronavirus, that when you have over-centralized national models of control they simply do not work:

Whether they are in the public sector or the private, the power of decision needs to be devolved to the people who have the tacit knowledge that comes from being practitioners, rather than centralized in Whitehall. Expertise matters too, but it is much easier to filter expert knowledge down than practitioner knowledge up. Expert knowledge, by its nature, is codifiable, and so readily shareable. Practitioner knowledge is tacit: it is intrinsically difficult to share because it can only be learned by doing.

Indeed, the same lessons being learned in the coronavirus pandemic are those learned by the failure of the centralized transmission model of schooling. The crucial point of engagement is in fact two-fold - that practitioner knowledge and the expertise of teachers are engaged and motivated through debate, and likewise, that strategies are pursued that cross the critical pedagogic threshold and thereby engage all students in the curriculum process and practice.

Vast resources and powerful communication infrastructures already exist to contribute to the formation of collective action. Each mutually arranged cooperative project group is a step toward young people building the necessary legacies that as adults they can employ 
to contribute to the formation of an effective public in ways that are reminiscent at least of Dewey's intentions for education in his laboratory school. The process is scalable globally. This has been proven by the global reach of the Cooperative Movement, which began with 28 people in Rochdale in England in 1844 (Woodin 2014) and is active in both the private and public sectors, including schools. This is what is potentially so frightening to neoconservative minds and rich elites, who want to maintain their privileged access to and positions in hierarchically ordered infrastructures.

What is holding us back?

\section{Reaching for conclusions}

Reactionary voices want us all to return to normal. Most likely we will. Indeed, there is a desperateness about a return to normal, however lined with fear. Hopefully, one day all this will seem like a lesson learned with no need to repeat the experience. But to learn it requires more than hope. It requires a curriculum founded upon real experiences, real practices, and real infrastructures that extend way beyond a given classroom and age group, one that can be carried forward into the lives of the adults capable of demanding a social system that meets their desires for a good life for all.

In schools, the teacher-student role needs to change. For example, the teacher may have a strong sense of what is important and what is trivial but in practice is dependent on what the student finds important-and that's a matter of deep personal response and not of intellectual assent to the teacher's "good reasons" for studying, whatever it is. The teacher may make decisions about what to teach, but the student decides what is learned, and may at one and the same time not be learning most of what the teacher teaches and intensively and actively learning things of which the teacher has no inkling. The glaring fact about contemporary school life is surely the predominant failure of teachers to teach many children the things they consider everyone should know. Indeed, it may be the illusion we all carry around with us that we can eliminate the failures if only we are given a little longer, if we work at it a bit harder, present the stuff a bit differently, use better material.

It is a myth: we cannot, and we do not. The model is wrong. Because it does not allow constructive feedback, it works against positive identification of individual failures to learn, and hence against a redefinition that such identification might suggest. In fact, national curricula particularly, those practiced in the UK, and to a lesser extent the US, are examples of national panic at the absence of ongoing patriotic identity projects (Goodson 2005a, b) rather than projects for the formation of socially just modes of governance globally.

We are looking to get individuals past the initial and fatal stumbling block that suspends alternative views and forms of organization. We are looking, in short, to cross a "pedagogic threshold" that currently holds back two thirds of our students (Blacker 2013); once we have crossed it, all manner of educational possibilities emerge.

Essential to this aim is cooperative and mutual learning, which unlike the prevailing methods, is inclusive of voices on a principle of freedom with equality. It enables each individual - teacher and student - to engage through reflections on experience and through dialog how each deals with "knowledge" and the circumstances of their lives. In this way, the teacher's knowledge is not something massive and fixed; it can be challenged and reinterpreted in ways that reveal new meaning for both student and teacher. The mutual education through cooperation is a spiral process. In its initial stages, the students kick the ideas around, bring their ideas to the teacher as the one who claims to know. The teacher may 
admit ignorance or contribute knowledge to the problem or issue, and thus together they reconfigure the problem/issue and identify pathways toward its solution. Those pathways are scalable through education in ways that can change the world, if teachers are up for the challenge.

\section{References}

APM Research Lab (2020). The color of coronavirus: Covid-19 deaths by race and ethnicity in the US. APM Research Lab. https://www.apmresearchlab.org/covid/deaths-by-race\#reporting.

Armstrong, M. (1974). The role of the teacher. In P. Buckman (Ed.), Education without schools. London: Souvenir Press.

Balibar, É. (1998). Spinoza and politics (Peter Snowdon, Trans.). London: Verso.

Balibar, E. (2010). La proposition de l'égaliberté [Proposition for an equafreedom]. Paris: PUF.

Benn, M. (2012). School wars: The battle for Britain's education. London: Verso.

Berliner, D. C., \& Glass, G. V. (2014). 50 myths and lies that threaten America's public schools: The real crisis in education. New York, NY: Teachers College Press.

Blacker, D. (2013). The falling rate of learning and the neoliberal endgame. Winchester: Zero Books.

Bloodworth, J. (2016). The myth of meritocracy: Why working-class kids get working-class jobs. London: Biteback Publishing.

Bloom, A. D. (1987). The closing of the American mind. New York, NY: Simon and Schuster.

Bouton, T. (2007). Taming democracy: "The people", the founders, and the troubled ending of the American revolution. Oxford: Oxford University Press.

Buchanan, J. M., \& Tullock, G. (1962). The calculus of consent: Logical foundations of constitutional democracy. Ann Arbor, MI: The University of Michigan Press.

Busby, M. (2020, September 27). UK schools told not to use anti-capitalist material in teaching. The Guardian. https://www.theguardian.com/education/2020/sep/27/uk-schools-told-not-to-use-anti-capitalist -material-in-teaching?ref=hvper.com.

Collier, P. (2020, May 6). Capitalism after coronavirus. New Statesman. https://www.newstatesman.com/ politics/economy/2020/05/capitalism-after-coronavirus.

Davidson, J. D., \& Rees-Mogg, W. (1997). The sovereign individual. How to survive and strive during the collapse of the welfare state. New York, NY: Simon \& Schuster.

Davis, A. (2018). Reckless opportunists. Elites at the end of the establishment. Manchester: Manchester University Press.

Dewey, J. (1927). The public and its problems. Athens, GA: Swallow Press.

Dewey, J. (1971). The child and the curriculum. Chicago, IL: University of Chicago Press.

Dewey, J. (1980). Democracy and education. The middle works (Vol. 8). Carbondale, IL: Southern Illinois University Press.

Dorling, D. (2015). Injustice. Why social inequality still persists. Bristol: Policy Press.

Earl, J., Moran, C., \& Ward-Perkins, Z. (2017). The econocracy: The perils of leaving economics to the experts. Manchester: Manchester University Press.

Eraut, M., MacKenzie, N., \& Papps, I. (1975). The mythology of educational development. British Journal of Educational Technology, 6(3), 20-34.

Facer, K. (2011). Learning futures: Education, technology and social change. Abingdon: Routledge.

Frankfurt, H. G. (2005). On bullshit. Princeton, NJ: Princeton University Press.

Fraser, K., \& Schostak, J. F. (2005). EdCity-A new learning environment. Manchester: British Computer Society.

Freire, P. (1972). Pedagogy of the oppressed (Myra Bergman Ramos, Trans.). Harmondsworth, Middlesex: Penguin.

Geoghegan, P., \& Fitzgerald, M. (2020, May 18). The 'lockdown sceptics' want a culture war, with experts as the enemy. The Guardian. https://www.theguardian.com/commentisfree/2020/may/18/lockdownsceptics-coronavirus-brexit.

Giroux, H. A. (1989). Schooling for democracy: Critical pedagogy in the modern age. London: Routledge.

Giroux, H. A. (2005). Cultural studies in dark times: Public pedagogy and the challenge of neoliberalism. Fast Capitalism. http://www.uta.huma/agger/fastcapitalism/1_2/giroux.htm.

Goodson, I. F. (2005a). Nations at risk and national curriculum. In I. F. Goodson (Ed.), Learning, curriculum and life politics: The selected works of Ivor F. Goodson. Abingdon: Taylor and Francis. 
Goodson, I. F. (2005b). Towards an alternative pedagogy. In I. F. Goodson (Ed.), Learning curriculum and life politics: The selected works of I. F. Goodson. London: Routledge.

Hanley, J. P., Whitla, D. K., Moo, E. W., \& Walter, A. S. (1970). Curiosity, competence and community. Man: A course of study. Cambridge, MA: Education Development Center.

Hirsch, A. (2020, April 8). If coronavirus doesn't discriminate, how come black people are bearing the brunt? The Guardian. https://www.theguardian.com/commentisfree/2020/apr/08/coronavirus-black-people-ethni c-minority-deaths-pandemic-inequality-afua-hirsch.

Jackson, P. W. (1968). Life in classrooms. New York, NY: Holt, Rinehart, \& Winston.

James, C. (1968). Young lives at stake. London: Collins.

Jameson, F. (1973). The vanishing mediator: Narrative structure in Max Weber. New German Critique. Winter, 52-89.

Jones, T. (2020, April 24). Italian lessons: What we've learned from two months of home schooling. The Guardian. https://www.theguardian.com/education/2020/apr/24/italy-home-schooling-coronavirus-lockd own-what-weve-learned.

Kakutani, M. (2018, April 24). The death of truth: How we gave up on facts and ended up with Trump. The Guardian. https://www.theguardian.com/books/2018/jul/14/the-death-of-truth-how-we-gave-up-on-facts -and-ended-up-with-trump.

Kilpatrick, W. H. (1951). Philosophy of education. New York, NY: MacMillan.

Kristol, I. (1995). Neoconservatism: The autobiography of an idea. Chicago, IL: Elephant Paperbacks.

Kwarteng, K., Patel, P., Raab, D., Skidmore, C., \& Truss, E. (2012). Britannia unchained: Global lessons for growth and prosperity. Basingstoke, NY: Palgrave Macmillan.

Laclau, E., \& Mouffe, C. (1985). Hegemony and socialist strategy: Towards a radical democratic politics. London: Verso.

Lowe, R. (1867a). Political speech, Hansard 3, 188, 15 July, col. 1549. https://api.parliament.uk/historic-hansa rd/commons/1867/jul/15/parliamentary-reform-representation-of\#column_1549.

Lowe, R. (1867b). Primary and classical education: An address delivered before the Philosophical Institutions of Edinburgh on Friday, November 1, 1867. Edinburgh: Edmonton \& Douglas.

Mack, M. (2010). Spinoza and the specters of modernity: The hidden enlightenment of diversity from Spinoza to Freud. London: Continuum.

McDonald, H. (2020, August 17). Domestic abuse surged in lockdown, panorama investigation finds. The Guardian. https://www.theguardian.com/society/2020/aug/17/domestic-abuse-surged-in-lockdown-panor ama-investigation-finds-coronavirus.

Miroff, N., \& Blanco, A. (2020). Trump ramps up border-wall construction ahead of 2020 vote. The Washington Post. https://www.washingtonpost.com/graphics/2020/national/immigration/border-wall-progress.

Mouffe, C. (2018). For a left populism. London: Verso.

Negri, A. (1991). The savage anomaly: The power of Spinoza's metaphysics and politics. Minneapolis, MN: University of Minnesota Press.

Norton, A. (2004). Leo Strauss and the politics of American empire. New Haven, CT: Yale University Press.

Oppel, R. A., Gebeloff, K. K., Lai, R., Wright, W., \& Smith, M. (2020, July 5). The fullest look yet at the racial inequity of coronavirus. The New York Times. https://www.nytimes.com/interactive/2020/07/05/us/coron avirus-latinos-african-americans-cdc-data.html.

Pilkington, E. (2020, May 9). 'You can’t ask the virus for a truce': Reopening America is Trump's biggest gamble. The Guardian. https://www.theguardian.com/us-news/2020/may/09/trump-reopening-america-coron avirus.

Pinar, W. F. (2019). What is curriculum theory? (3rd ed.). New York, NY: Routledge.

Quiggin, J. (2010). Zombie economics: How dead ideas still walk among us. Princeton, NJ: Princeton University Press.

Rancière, J. (1987). Le maître ignorant: Cinq leçons sur l'émancipation intellectuelle [The ignorant schoolmaster: Five lessons in intellectual emancipation]. Paris: Fayard.

Rancière, J. (2001). Ten theses on politics. Theory \& Event. https://doi.org/10.1353/tae.2001.0028.

Raths, J. D. (1971). Teaching without specific objectives. Educational Leadership, 28, 714-720.

Reagan, R. (1983). "Evil empire” speech. Voices of Democracy, The US Oratory Project. http://voicesofde mocracy.umd.edu/reagan-evil-empire-speech-text/.

Reay, D. (2017). Miseducation: Inequality, education and the working classes. Bristol: Policy Press.

Rivera, C., Hsu, Y.-C., Esbry, F. P., \& Dugarova, E. (2020). Gender inequality and the Covid-19 crisis: A human development perspective. New York, NY: UNDP.

Rosanvallon, P. (2013). The society of equals (Arthur Goldhammer, Trans.). Cambridge, MA: Harvard University Press.

Sandlin, J. A., Schultz, B. D., \& Burdick, J. (2010). Handbook of public pedagogy: Education and learning beyond schooling. New York, NY: Routledge.

Schmitt, C. (1985). Political theology. Four chapters on the concept of sovereignty (George Schwah, Trans.). Chicago, IL: University of Chicago Press. 
School of Barbiana (1969). Letter to a teacher (Nora Rossi and Tom Cole, Trans.). Harmondsworth, Middlesex: Penguin.

Schostak, J. F. (Ed.) (1988). Breaking into the curriculum: The impact of information technology on schooling. London: Methuen.

Schostak, J. F. (2014). Supersurveillance, democracy and cooperation-The challenge for teachers. Asia-Pacific Journal of Teacher Education, 4, 324-336.

Schostak, J. F., \& Goodson, I. F. (2020). Democracy, education and research: The struggle for public life. London: Routledge.

Schostak, J. F., Hammersley-Fletcher, L., \& Clarke, M. (2020). Paradoxes of democracy, leadership and education: Struggling for social justice in the twenty-first century. London: Routledge.

Scotland, P. (2020, May 30). Covid-19 has led to a rise in domestic violence-Tackling this hidden pandemic requires concerted action. The Independent. https://www.independent.co.uk/voices/coronavirus-covid-19pandemic-domestic-violence-commonwealth-a9540091.html.

Shor, I. (1996). When students have power: Negotiating authority in a critical pedagogy. Chicago, IL: University of Chicago Press.

Smith, D. (2020, April 23). Coronavirus: Medical experts denounce Trump's theory of 'disinfectant injection'. The Guardian. https://www.theguardian.com/world/2020/apr/23/trump-coronavirus-treatment-disinfecta nt.

Spinney, L. (2020, April 12). Inequality doesn't just make pandemics worse-It could cause them. The Guardian. https://www.theguardian.com/commentisfree/2020/apr/12/inequality-pandemic-lockdown.

Stenhouse, L. (1975). Defining the curriculum problem. Cambridge Journal of Education, 5(2), 104-108.

Strauss, L. (1988). What is political philosophy? And other studies. Chicago, IL: University of Chicago Press.

Taub, A. (2020, April 6). A new Covid-19 crisis: Domestic abuse rises worldwide. The New York Times. https:// www.nytimes.com/2020/04/06/world/coronavirus-domestic-violence.html.

Thatcher, M. (1984). Speech to 1922 Committee ("The enemy within"). Margaret Thatcher Foundation. http:// www.margaretthatcher.org/document/105563.

Ward, L. (2014). Modern democracy and the theological-political problem in Spinoza, Rousseau and Jefferson. New York, NY: Palgrave Macmillan.

Waxman, O. B. (2020, September 17). Echoing decades of fighting over US history classrooms, President Trump announces a push for 'patriotic education'. Time. https://time.com/5889907/trump-patriotic-educa tion/.

Weber, M. (2014). The spirit of work and vocation. Second lecture: Politics as vocation. (Dagmar Waters, Benjamin Elbers, and Tony Waters, Trans. and Eds.). Chico, CA, \& Hamburg: Verlag Duncker \& Humboldt.

WHO [World Health Organization] (2008). Report from the committee on the social determinants of health. Geneva: WHO. http://www.who.int/social_determinants/thecommission/finalreport/en/.

Wilson, P. S. (1971). Interest and discipline in education. London: Routledge \& Kegan Paul.

Woodin, T. (Ed.) (2014). Co-operation, learning and co-operative values contemporary issues in education. Abingdon: Routledge.

Publisher's Note Springer Nature remains neutral with regard to jurisdictional claims in published maps and institutional affiliations.

Ivor F. Goodson is currently International Research Professor at the University of Tallinn, Estonia, and a Senior Research Associate at the Guerrand-Hermès Foundation for Peace Research Institute, in the UK. Ivor became a Fellow of the Academy of Social Sciences in 2019, and, in 2018, received the John Nisbet Fellowship Award for outstanding contribution to educational research over his career by BERA. In 2016, he was nominated for inclusion in the forthcoming 2000 Outstanding Intellectuals of the twenty-first Century 10th Edition and for entry in The Routledge Encyclopaedia of Educational Thinkers - this was the only entry for a serving academic, representing England and Europe.

John F. Schostak is Emeritus Professor at Manchester Metropolitan University (MMU). Before joining MMU, he was Professor and Director of the Centre for Applied Research in Education, University of East Anglia. Over the years, he led around 70 funded projects and drew upon that experience in his publications focusing on research methodology and the issues of bringing about change. These include, with Jill Schostak, Radical Research (Routledge, 2008), Researching Violence, Democracy and the Rights of People (Routledge, 2010), Writing Critically (Routledge, 2013), and, most recently, with Ivor Goodson, Democracy, Education and Research: The Struggle for Public Life (Routledge, 2020). 